\title{
Reconstruction of Death Penalty Sanctions for Corruption Perpetrators in Indonesian Law
}

\author{
Tinuk Dwi Cahyani ${ }^{1}$ \\ \{tinukcahyani@yahoo.com ${ }^{1}$ \} \\ Faculty of Law, University of Muhammadiyah Malang, Indonesia ${ }^{1}$
}

\begin{abstract}
Corruption has been through an uncontrollable development, even in criminological studies, perpetrators of corruption have prepared legal instruments to deceive the prosecution of the public prosecutor because corruption seems to be a legitimate and legal transaction. In committing corruption, often it is not done by an individual, even in groups, in a congregation with many relatives, especially in institutions, agencies such as the legislature. Seeing it is done together or in one group as if at first the act was against the law, then it becomes the act that is not illegal was done because many people did it. This is what is interesting to study, in order the perpetrators are deterred and effective in preventing criminal acts of corruption, which in Law Number 31 of 1999 concerning Eradication of Corruption Article 2 Paragraph (2) In the case of criminal acts of corruption as referred to in paragraph (1) carried out in certain circumstances, the death penalty may be imposed. What is meant by $\wedge^{\wedge}$ certain circumstances ${ }^{\wedge}$ in this provision is meant as a deterrent to the perpetrator of the criminal act of corruption if the criminal act is committed when the country is in a state of danger under the applicable law when a natural disaster that affects state as a whole occurs, as a repetition of the criminal act of corruption. or when the country is in a state of economic and monetary crisis. In this case, the researcher is interested in taking the formulation of the problem of proper reconstruction for Article 2 paragraph (2) of Law Number 31 of 1999 concerning Eradication of Corruption to be effective. The legal methodology used is the juridical normative method. The approach used is the statue approach and the comparative approach. Types and sources of legal materials used are primary legal materials, in the form of legislation and secondary legal materials in the form of libraries in the field of law and scientific articles from both newspapers and the internet.
\end{abstract}

Keywords: Corruption, death penalty sanctions, indonesian law

\section{Introduction}

When talking about corruption, the people from the lower level to the top of society have recognized and it becomes a hot yet exciting conversation because it is reported on television, which means that people in Indonesia can easily access information from television media. Because it has become a public discussion by the society so that the public is "not surprised anymore" if there are corruption cases that are revealed and reported on television.

Corruption is also still a hot issue and has become a campaign material and has even become a commodity in order to gain populist legitimacy with promises to eradicate corruption for Presidential Candidates. In other words, the corruption theme is very down to earth. However, 
on the other hand, it raises new concerns, because the term corruption is so popular, it has the potential to shift the meaning of corruption itself. Especially amid the reality of the incessant eradication of corruption which is deemed incapable of reducing the level of corruption itself. Such conditions may place that corruption, which should be classified as a serious crime and must be condemned, can shift into something that seems normal. If this happens, it will be increasingly difficult to eradicate corruption, because society can be led to permissiveness and apathy in responding to the phenomenon of corruption. [1]

From here, several politicians took advantage of the momentum and made promises regarding the eradication of corruption. Providing promises to the people, that it will make a clean government free from corruption and carry out law enforcement and impose penalties for corruptors. Even though the presence of politicians is expected to be able to solve various problems they face, including the problem of corruption that has taken state money, which results in the people being disadvantaged in the hope that the perpetrators of corruption will receive a severe punishment [7].

The increasing frequency of the death penalty in Indonesia is more dominated by the distribution and trafficking of illegal drugs such types drugs (narcotics, psychotropic substances, and addictive substances) compared to the increase in violent crime. In an impartial record, for the period 1998-2008, narcotics and psychotropic cases were cases with quite a several death sentences, namely 68 cases, followed by 32 cases of murder offenses. [2]

The difficulty in overcoming corruption can be seen from the many acquittals of the accused in corruption cases or the minimum amount of punishment the defendant has borne. This is very detrimental to the state and hinders nation-building. If this happens continuously for a long time, it can negate the sense of justice and a sense of trust in the laws and regulations by society. The problem of corruption is a national problem that is not simple. Several factors make this happen, at least because the actors who commit corruption crimes are people who have a lot of money and extensive networks. So that when they get caught up in the law, they will use their money and power to avoid or buy the law [3]. In this case, the author takes the formulation of the problem how is the proper reconstruction of Article 2 paragraph (2) of Law Number 31 of 1999 in conjunction with Law Number 20 of 2001 concerning the Eradication of Corruption to be effective?

\section{Methods}

The legal methodology used is normative juridical. The approach method used is the statue approach and the comparative approach. Types and sources of legal materials used are primary legal materials, which is legislation, and secondary legal materials libraries in the field of law and scientific articles from both newspapers and the internet. Technique collection of legal materials used is literature study and access Internet. The legal material analysis technique is using the content method analysis and the conceptual definitions used are the Corruption Crime, the Death Penalty, and the attempt to reconstruct Article 2 paragraph (2) of Law Number 31 Year 1999 concerning Corruption Eradication. 


\section{Results and Discussion}

To tackle the crime of corruption as an extraordinary crime, legislators formulate several important things that are considered to be used as tools to ensnare and bring a deterrent effect to the perpetrator, namely the principle of reversal of proof and severe sanctions, including capital punishment. The policy for the formulation of articles relating to these two matters is certainly based on thoughts and is motivated by the desire to eradicate the criminal act of corruption. However, this formulation policy is not followed by an application policy. As the principle of reverse proof is reluctant to be applied in trials of corruption crimes, judges of corruption are also reluctant to impose the death penalty against the perpetrators of criminal acts, even though the state has lost billions, even trillions of rupiah, and many members of the society have lost the opportunity to enjoy the welfare resulting from the crime.

Article 2 paragraph (1) and (2) of the Corruption Eradication Law which regulates that a perpetrator can be convicted of death has never been applied because certain conditions are not fulfilled by corruptors. This indicates that, apart from repetition of criminal acts, the imposition of capital punishment against corruptors can only be done if the state is in an "extraordinary" situation, namely the state is in a state of danger under the applicable law, such as a national natural disaster, or when the country is in a state of economic and monetary crisis. An unusual condition, the parameters of which require a long debate. [4]

Can be sentenced to death to any person who illegally commits an act of enriching himself or another person or a corporation that can harm the state finances or the state economy as stipulated in Article 2 paragraph (2) of Law Number 31 Year 1999 which is carried out in "certain circumstances "Is the punishment for the perpetrators of corruption.

Although legally, the application of the death penalty has been regulated since 1999, in practice, until now, no corruptor has been sentenced to death. Indonesia should be able to reflect on China in enforcing the law against corruption, China there is no mercy for corruptors, even Cheng Ke Jie, deputy chairman of the Chinese Parliament was sentenced to death, Ju Rongji, the Prime Minister of China a few years ago said "prepare thousands of coffins for corruptors, but Also prepare a coffin for me, if I am also corrupt, I am ready to be sentenced to death. " Ju Rongji's words should inspire Indonesian leaders to be firm in eradicating corruption indiscriminately. [5]

Article 2 paragraph (1) and (2) of the Corruption Eradication Law which regulates that a perpetrator can be convicted of death has never been applied because certain conditions are not fulfilled by corruptors. This indicates that, apart from repetition of criminal acts, the imposition of capital punishment against corruptors can only be done if the state is in an "extraordinary" situation, namely the state is in a state of danger under the applicable law, such as a national natural disaster, or when the country is in a state of economic and monetary crisis. An unusual condition, the parameters of which require a long debate. Based on this reality, the question that then arises is, is it still relevant to formulate the death penalty in future corruption crimes? This is based on the discourse of the need to revise the Corruption Eradication Law because it still has weaknesses, among others, no provision regulates sexual gratification, and reversed proof provisions that law enforcers rarely use. Besides, capital punishment is still maintained in the Draft Criminal Code with certain circumstances and is always threatened with alternatives [6]

From the explanation above, the criminal law instrument must be able to be a means to prevent public morality, so that the people are not led by people who have been given public trust by they yet on the contrary have betrayed them. Thus, law enforcement officers are not only guided by the specificities of the regulation of the law on corruption, the appropriateness of the elements of the article but see the law from the technical side of the law and at the same 
time the legal objectives to be achieved. If this is the case, the objectives of justice, legal certainty, and legal benefits will always be reflected in the entire law enforcement process starting from the stage of the investigation, prosecution to implementation of court decisions. The law does require judges to explore and follow the values that live in society. And from the perspective of the community, to punish the perpetrators of corruption as much as possible with relatively heavy penalties, because if the perpetrators of corruption are sentenced to light crimes, even acquitted from all lawsuits, many people consider the ruling to be unfair.

\section{Conclusion}

In conclusion, Article 2 paragraph (1) and (2) of the Corruption Eradication Law which regulates that a perpetrator can be convicted of death, in fact has never been applied; thus the imposition of capital punishment against corruptors can only be done if the state is in an "extraordinary" situation, namely the state is in a state of danger under the applicable law, such as a national natural disaster, or when the country is in a state of economic and monetary crisis. An unusual condition, the parameters of which require a long debate. While the revision of the Corruption Eradication Law is because it still has weaknesses, among others, no provision regulates sexual gratification and reversed proof provisions that are rarely used by law enforcers. Besides, capital punishment is still maintained in the Draft Criminal Code with a special nature and is always threatened with alternatives. Thus, the criminal law instrument must be able to be a means to prevent public morality, so that the people are not led by people who have been given public trust by they yet on the contrary have betrayed them. The law does require judges to explore and follow the values that live in society. And from the perspective of the community, to punish the perpetrators of corruption as much as possible with relatively heavy penalties in order to give an effective deterrent effect.

\section{References}

[1] Y. Kristiana, Pemberantasan Tindak Pidana Korupsi Perspektif Hukum Progresif, Yogyakarta: Thafa Media, 2016, p. 28.

[2] A. J. Salam, Polemik Hukuman Mati di Indonesia (Perspektif Islam HAM dan Demokratisasi Hukum), Jakarta: Badan Litbang dan Diklat Kementerian Agama, 2010, pp. 4 - 5.

[3] Sulistyowati, Perempuan dan Hukum: Menuju Hukum yang Berspektif Keseteraan dan Keadilan, Jakarta: Yayasan Obor Indonesia, 2006, p. 271.

[4] E. R. M. Toule, "Eksistensi Ancaman Pidana Mati dalam Undang-undang Tindak Pidana Korupsi," Jurnal Hukum PRIORIS , vol. III, p. 107, 2013.

[5] I. Darmawan, "Universitas Pakuan," 14 July 2016. [Online]. Available: www.unpak.ac.id/pdf/pro_kontra.pdf .

[6] "Rancangan Undang Undang KUHP yang Diserahkan oleh Pemerintah Kepada DPR RI," 2012.

[7] Wardani, R., Chrismonita, V. N., Damaika, R., \& Basri, B. (2019). Dasar Pertimbangan Penyidik Polres Magelang dalam Penentuan Alat Bukti Tindak Pidana Korupsi. Borobudur Law Review, 1(1), 46-59. 